\title{
Effect of Pre-Harvest Treatments of Peach Trees on Fruits Quality Characters during Cold Storage El-Dengawy, E. F. A. ${ }^{1}$; M. A. El-Shobaky ${ }^{2}$ and T. A. A. Serag ${ }^{2}$ \\ ${ }^{1}$ Pomology Department, Faculty of Agriculture, Damietta University, Egypt. \\ ${ }^{2}$ Fruit Trading Department, Horticulture Research Institute, Agricultural Research Center, Giza, Egypt.
}

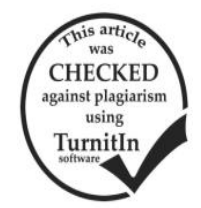

\begin{abstract}
This research was carried out during two successive seasons of 2016 and 2017 to study the effect of pre-harvest treatments on peach trees on fruits quality at harvest time and during cold storage at $5 \pm 1{ }^{\circ} \mathrm{C}$ and $80-85 \% \mathrm{RH}$. The selected trees for this study were chosen from locally Mit-Ghamer peach trees(cv. Medium Sultani), grown in a private orchard at Fesha-Bana village, Aga Center, Dakahllia governorate, Egypt. The selected trees of peach (cv. Medium Sultani) were sprayed Pre-harvest (1.5 month after full bloom) with one of the followings: tap water (control), $1.5 \%$ potassium sulphate $\left(\mathrm{K}_{2} \mathrm{SO}_{4}\right), 2 \%$ calcium chloride $\left(\mathrm{CaCl}_{2}\right)$ and the combination of them. The harvested mature fruits were cold stored at $5 \pm 1{ }^{\circ} \mathrm{C}$ and $80-85 \%$ relative humidity $(\mathrm{RH})$ for a storage period of 24 days. Some physical and chemical quality characteristics were measured on the intact treated fruits at harvest date and at 6-day-intervals during cold storage up to 24 days. The obtained results showed that the peach fruits sprayed with $1.5 \% \mathrm{~K}_{2} \mathrm{SO}_{4}$ recorded the highest values of firmness, Vitamin C content and TSS\% after 6,12 and 18 days during The cold storage in both seasons. While, peach trees sprayed with $2 \% \mathrm{CaCl}_{2}$ gave the highest values of fruit firmness at harvest time and after 24 days of cold storage, and the lowest value of fruits decay incidence $\%, \mathrm{TSS} \%$ and anthocyanin content in fruit skin in all storage periods of both seasons. Applying the combination treatment of $1.5 \% \mathrm{~K}_{2} \mathrm{SO}_{4}$ and $2 \% \mathrm{CaCl}_{2}$ showed the highest values of vitamin $\mathrm{C}$, acidity and total sugars $\%$, anthocyanin and pectic substances contents as well as the lowest value of TSS/acid ratio and weight loss \% of fruit at 18 and 24 days of cold storage in both seasons. However, the opposite trends were true for the control treatment. Finally, it can be recommended applying the combination spray of 1.5 $\% \mathrm{~K} 2 \mathrm{SO} 4$ and $2 \% \mathrm{CaCl} 2$ on peach trees at pre-harvest (1.5 month after full bloom) to improve maintaining physical and chemical qualities of peach fruits during cold storage up to 24 days.
\end{abstract}

Keywords: Peach, Prunus persica, pre-harvest treatments, potassium sulphate, calcium chloride, quality characters, cold storage.

\section{INTRODUCTION}

The peach, Prunus persica L. (Bastch) is one of the most preferred fruits for consumers in the world wide because of its high nutrient level and pleasant flavor. The fruit may be consumed fresh or processed into jelly and jam. Peach is considered one of the most important deciduous fruit that greatly success and widespread in the newly reclaimed areas in Egypt. The total cultivated area of peach in 2017 season was about 58803 feddans with total production of 360723 tons fruits, according to Food and Agriculture Organization (FAO, 2019).

Peach is a climacteric fruit, which undergoes rapid ripening. This is responsible for its short shelf-life and represents a serious constraint for its efficient handling and transportation (Hussain et al., 2008). So, there is a great role of pre-harvest horticultural applications to improve of fruits quality.

Potassium $(\mathrm{K})$ is thought to plays an important role in metabolic reactions related to the maturity and senescence of fruits. It was reported that the foliar applications of potassium $\left(\mathrm{K}_{2} \mathrm{SO}_{4}\right)$ increased cherry fruit firmness (Matzner and Maurer, 1975) and improved fruit quality in "Royal Glory" peach include soluble solids content and fruit appearance (Ben et al., 2009). Applying three sprays with $1.5 \%$ potassium nitrate significantly improved the fruit size of pear as compared to control (Gill et al,.2012). Pre-harvest spraying peach trees with potassium nitrate at $2 \%$ by Kaur et al. (2012) increased fruit weight, TSS and TSS: acid ratio, but reduced firmness and acidity of fruits. Jumaa and Ali (2016) showed that foliar application pomegranate trees with potassium sulfate at the rate of $3000 \mathrm{mg} \mathrm{L}^{-1}$ significantly decreased fruit cracking by $18.7 \%$, which led to increasing in fruit weight and fruit yield and some of the physical qualities of fruits. Kumar et al. (2017) revealed that the foliar spraying of potassium sulphate improved quality parameters over the control. Where, the highest fruit firmness, total soluble solids, total sugars, pectin content and ascorbic acid content and lowest acidity were recorded in guava plants sprayed with potassium sulphate at $3 \%$.

Calcium sprays are applied universally during fruit development to maximize storage potential and minimize the risk of calcium-related storage disorders (Ernani et al., 2002). Many pre-harvest calcium treatments are effective in overcoming several physiological disorders and this fact is attributed to the ability and efficiency of calcium to maintain cell membrane and wall integrity and structure relating with pectin polymers and keeping cell cohesiveness (Glenn and Poovaiah, 1990). Pre-harvest $\mathrm{Ca}^{2+}$ treatments used to increase $\mathrm{Ca}^{2+}$ content of the cell wall were effective in delaying senescence, resulting in firmer fruits have a higher quality (Raese and Drake, 2006). The pear trees treated with calcium chloride at $2.0 \%$ concentration (Prasad et al., 2015) recorded the highest value of both titratable acidity $(0.46 \%)$ and ascorbic acid $(6.42 \mathrm{mg} / 100 \mathrm{~g})$ compared to other treatments. Gayed et al. (2017) showed that pre-harvest application with $2 \% \mathrm{CaCl}_{2}$ was most effective in minimizing decay $\%$ and weight $10 s s \%$ as well as in maintaining maximum firmness and lengthening shelf life. Singh et al. (2017) showed that peach fruits treated with $\mathrm{CaCl}_{2}(0.6 \%)$ reduced the physiological loss in weight, maintained fruit firmness and content of acidity, TSS and ascorbic acid under both ambient and refrigerated conditions. Sharma and Pratima (2018) stated that foliar application of calcium nitrate (1\%) was found to be superior over calcium chloride (2\%) for improving peach fruit quality (TSS, acidity and firmness) and reducing fruit deterioration during shelf life.

Peach ripen and deteriorate quickly at ambient temperature. Therefore, cold storage has always been used as the main method to slow these processes as well as decay development, but chilling injury limits peach storage life at low temperatures (Wang et al., 2006). The weight loss, decay percentage and TSS/acid ratio of the peach 
fruits were gradually increased by increasing cold storage period. While, fruit pulp firmness, TSS and acidity were decreased (Gad et al., 2016 and Kaur and Kaur, 2019).

Therefore, the main goal of this research is to study the effect of pre-harvest treating peach trees by the spraying with potassium sulphate or calcium chloride alone or in combination on the physical and chemical characteristics of peach fruits quality during cold storage $\left(5 \pm 1{ }^{\circ} \mathrm{C}\right.$ and $\left.80-85 \% \mathrm{RH}\right)$.

\section{MATERIALS AND METHODS}

The present study was carried out during two successive seasons of 2016 and 2017 on locally MitGhamer peach trees (Prunus persica L.) Medium Sultani (Eliwa,2005) grown in aprivate orchard at Fesha-Bana vallage, Aga center, Dakahllia governorate, Egypt.The selected trees were about 35-years-old, almost uniform grown in clay soil, spaced at $5 * 4$ meters apart, received irrigation and fertilization programs along with other cultural practices according to recommendation of the Agriculture Ministry to clay soil conditions.

Twenty four trees were selected and randomly divided into four equal groups, 6 trees each. Every one group was sprayed pre-harvest (1.5 months after full bloom) by one of the following treatments: Tap water (control $\left.=\mathrm{T}_{1}\right)$, Potassium sulphate at 1.5\% $\left(\mathrm{T}_{2}\right)$, Calcium chloride at $2 \%\left(\mathrm{~T}_{3}\right)$ and a combination of the two salts $\left(\mathrm{T}_{4}\right)$.

At harvest date, 120 mature fruits were collected from each treatment and immediately transported to the laboratory of Pomology Department, Faculty of Agriculture, Damietta University, washed with tap water and soup, to remove impurities and microbial load on the fruit surfaces, and dried using electrical fan. These fruits were sorted for uniformity in size, shape, maturity and freedom from defects.

Fruits were refrigerated at low temperature $\left(5 \pm 1^{\circ} \mathrm{C}\right)$ and $80-85 \%$ relative humidity $(\mathrm{RH})$ for storage period of 24 days. The following physical and chemical characteristics of fruits quality at harvest date and during cold storage periods at 6-day-intervals were measured.

\section{A- Physical characteristics}

The physical characteristics were measured on the intact treated fruits in 3 replicates (40 fruits each) per treatments as follows:

1. Fruit firmness (lb. $/ \mathbf{i n}^{2}$ ) was determined by Magness and Taylor (1925) pressure tester using a 5/16 plunger.

2. Fruit weight loss (\%): The initial weight of each replicate was recorded at the starting of cold storage. Changes in fruits weight were measured by reweighting at 6-day-intervals during cold storage period up to $24^{\text {th }}$ day. The weight loss percentage was calculated in relation to its initial weight according the following equation:

Weight loss $(\%)=\frac{\text { Initial weight }- \text { Sample weight }}{\text { Initial weight }} \times 100$

3. Fruits decay incidence (\%): Percentage of decay incidence was obtained from the number of fruits that showed signs of decay over the initial number of fruits.

B- Chemical characteristics

These characteristics were determined in 3 replicates per treatment. Four fruits per replicate were homogenized and the homogenate filtered through several layers of cheese cloth to obtain the clear juice. The procedures of determinations were as follows:

1. Vitamin C content ( $\mathbf{m g} / \mathbf{1 0 0} \mathrm{ml}$ juice) was determined in fruit juice as described by Ranganna (1979).

2. Titratable acidity (\%) was measured in $3.0 \mathrm{ml}$ per replicate by titrating the fruit juice after diluting with distilled water, against $0.1 \mathrm{~N}$ sodium hydroxide $(\mathrm{NaOH})$ solution in the presence of phenolphthalein as an indicator to the end point (Ranganna, 1979).

3. Total soluble solids (TSS \%) was measured in using an Abe hand refractometer.

4.Total soluble solids/acid ratio was calculated from the results recorder for $\mathrm{TSS} \%$ and titratable acidity $\%$ determinations.

5. Total soluble sugars were determined according to the method described by Sadasivam and Manickam (1996) and the obtained result was represented as a percentage.

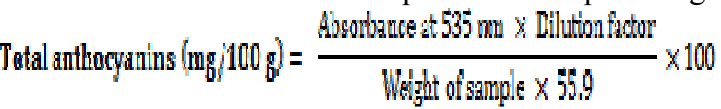

6. Anthocyanin content $(\mathbf{m g} / \mathbf{1 0 0 g})$ : Half gram of fresh skin of peach fruits was extracted in $10 \mathrm{ml}$ of acidified ethanol alcohol solution, for $24 \mathrm{hr}$ under laboratory temperature. The extract was measured at $535 \mathrm{~nm}$ using Spectrophotometer according to the methods of Husia et al., (1965). The content of total anthocyanin in peach skin was calculated using the following equation as described by Francis and Chiriboga (1973):

7. Determination of pectic substances\% was made according to Ranganna (1979).

\section{Statistical analysis}

The experiment was laid out in randomized complete blocks design. The differences among treatment means were compared with Duncan Multiple Range tests at a significant level of $P<0.05$ using the Statistical Analysis System of SAS Package(1996).

\section{RESULTS AND DISCUSSION}

\section{Physical characters:}

Fruit firmness, weight loss and decay incidence percentages of peach fruits as affected by pre-harvest spraying treatments at 6-days intervals under cold storage up to 24days during 2016 and 2017 seasons were presented in Table (1).

The results showed that pre-harvest spraying of $\mathrm{CaCl}_{2}$ spraying achieved the highest firmness of fruits compared to spraying with $\mathrm{K}_{2} \mathrm{SO}_{4}$ or control. Increasing the duration of cold storage gradually reduced fruit firmness. After 24 days of cold storage, the control fruit firmness was decreased to a minimum value of $2.35 \mathrm{lb} / \mathrm{in}^{2}$ as an average of the two seasons of study, while the $\mathrm{CaCl}_{2}$ treated fruits retained a higher firmness than the control by $40.4 \%$ followed by the $\mathrm{K}_{2} \mathrm{SO}_{4}$-treated fruits, which increased by $28.1 \%$ over control fruits. Such are in results agreement with the previous study indicated that fruit firmness was increased significantly with different potassium treatments as compared to firmness of control (non-treated pear fruits) (Gill, et al., 2012). Applications of potassium increased osmoregulation of cell vacuoles and maintained the equilibria, resulting in firm fruits (Wani and Khajwall, 1997). 
The improvement in the fruits firmness associated with pre - harvest spraying with $\mathrm{CaCl}_{2}$ may be due to the role of calcium in maintaining cell wall structure in fruits by interacting with pectin in the cell wall to form calcium pectate which assists molecular bonding between constituent of the cell wall (Dong et al., 2000). Calcium is known to strengthen the structure of cells by maintaining the fibrous packaging in the cell walls, thus reinforcing contact of the cell to cell, which is related to the formation of calcium pectate and counteracts the pectin methyl esterase activity as observed in calcium treated pear fruits (Alandes et al., 2009).

Fruits of control showed the highest weight loss during cold storage periods of 6 to 24 days. The percentage of weight loss in stored fruits increased with the progress of cold storage period. Most effective treatment in reducing weight loss was the treatment of $\mathrm{CaCl}_{2}$ spraying (22.4\%) followed by the combination of $\mathrm{CaCl}_{2}$ and $\mathrm{K}_{2} \mathrm{SO} 4(22.9 \%)$ compared to control (26.5\%) as an average of the two seasons of study at the last day of storage (24days).

Table 1. Fruit firmness, weight loss and decay incidence percentages of peach fruits as affected by pre-harvest spraying potassium sulphate, calcium chloride and their combination at 6-days intervals of cold storage during 2016 and 2017 seasons.

\begin{tabular}{|c|c|c|c|c|c|c|c|c|c|c|}
\hline \multirow{3}{*}{$\begin{array}{l}\text { Treatments } \\
\text { Seasons }\end{array}$} & \multicolumn{10}{|c|}{ Intervals of cold storage in days } \\
\hline & \multicolumn{2}{|c|}{$\mathbf{0}$} & \multicolumn{2}{|c|}{6} & \multicolumn{2}{|c|}{12} & \multicolumn{2}{|c|}{18} & \multicolumn{2}{|c|}{24} \\
\hline & 2016 & 2017 & 2016 & 2017 & 2016 & 2017 & 2016 & 2017 & 2016 & 2017 \\
\hline \multicolumn{11}{|c|}{ Fruit firmness $\left(\mathrm{lb} / \mathrm{in}^{2}\right)$} \\
\hline $\mathrm{T}_{1}$. Control treatment & $4.33 \mathrm{c}$ & $4.47 \mathrm{c}$ & $3.07 \mathrm{c}$ & $3.12 \mathrm{c}$ & $2.97 \mathrm{c}$ & $3.08 \mathrm{c}$ & $2.37 \mathrm{~d}$ & $2.47 \mathrm{~d}$ & $2.28 \mathrm{c}$ & $2.42 \mathrm{c}$ \\
\hline $\mathrm{T}_{2} . \mathrm{K}_{2} \mathrm{SO}_{4}$ at $1.5 \%$ & $6.23 \mathrm{~b}$ & 7.07ab & $5.17 \mathrm{a}$ & $5.68 \mathrm{a}$ & $4.36 \mathrm{~b}$ & $4.66 \mathrm{~b}$ & $3.47 \mathrm{~b}$ & $3.74 \mathrm{~b}$ & $2.97 \mathrm{ab}$ & $3.05 \mathrm{~b}$ \\
\hline $\mathrm{T}_{3} \mathrm{CaCl}_{2}$ at $2.0 \%$ & $7.97 \mathrm{a}$ & $8.25 \mathrm{a}$ & $5.64 \mathrm{a}$ & $5.92 \mathrm{a}$ & $5.03 \mathrm{a}$ & $5.33 \mathrm{a}$ & $4.20 \mathrm{a}$ & $4.15 \mathrm{a}$ & $3.25 \mathrm{a}$ & $3.37 \mathrm{a}$ \\
\hline $\mathrm{T}_{4} . \mathrm{K}_{2} \mathrm{SO}_{4}$ at $1.5 \%+\mathrm{CaCl}_{2}$ at $2.0 \%$ & $6.20 \mathrm{~b}$ & $6.40 \mathrm{~b}$ & $4.66 \mathrm{~b}$ & $4.76 \mathrm{~b}$ & $3.00 \mathrm{c}$ & $3.10 \mathrm{c}$ & $2.78 \mathrm{c}$ & $3.02 \mathrm{c}$ & $2.37 \mathrm{c}$ & $2.43 \mathrm{c}$ \\
\hline \multicolumn{11}{|c|}{ Fruit weight loss (\%) } \\
\hline $\mathrm{T}_{1}$. Control treatment & 0.00 & 0.00 & $8.39 \mathrm{a}$ & $6.99 \mathrm{a}$ & $14.82 \mathrm{a}$ & $12.22 \mathrm{a}$ & $18.69 \mathrm{a}$ & $19.00 \mathrm{a}$ & $27.90 \mathrm{a}$ & $25.17 \mathrm{a}$ \\
\hline $\mathrm{T}_{2} . \mathrm{K}_{2} \mathrm{SO}_{4}$ at $1.5 \%$ & 0.00 & 0.00 & $6.00 \mathrm{~b}$ & $4.26 \mathrm{~b}$ & $12.11 \mathrm{~b}$ & $8.36 \mathrm{~b}$ & $16.75 b c$ & $15.17 b$ & $25.93 b$ & $22.98 b$ \\
\hline $\mathrm{T}_{3} \cdot \mathrm{CaCl}_{2}$ at $2.0 \%$ & 0.00 & 0.00 & $5.72 b$ & $5.44 \mathrm{~b}$ & $11.58 \mathrm{bc}$ & $6.95 \mathrm{c}$ & $17.52 \mathrm{ab}$ & $17.59 \mathrm{a}$ & $24.14 \mathrm{c}$ & $20.64 c$ \\
\hline $\mathrm{T}_{4} . \mathrm{K}_{2} \mathrm{SO}_{4}$ at $1.5 \%+\mathrm{CaCl}_{2}$ at $2.0 \%$ & 0.00 & 0.00 & $3.76 \mathrm{c}$ & $4.46 \mathrm{~b}$ & $11.00 \mathrm{c}$ & $6.89 \mathrm{c}$ & $15.91 \mathrm{c}$ & $13.62 b$ & $25.14 \mathrm{~b}$ & $20.58 \mathrm{c}$ \\
\hline \multicolumn{11}{|c|}{ Fruits decay incidence $(\%)$} \\
\hline $\mathrm{T}_{1}$. Contr & 0.00 & 0.00 & $5.92 \mathrm{a}$ & 0.00 & $21.71 \mathrm{a}$ & $8.54 \mathrm{a}$ & $37.17 \mathrm{a}$ & $13.27 \mathrm{~b}$ & $63.29 \mathrm{a}$ & $47.35 \mathrm{a}$ \\
\hline $\mathrm{T}_{2} . \mathrm{K}_{2} \mathrm{SO}_{4}$ at $1.5 \%$ & 0.00 & 0.00 & $0.00 \mathrm{~b}$ & 0.00 & $10.90 \mathrm{~b}$ & $8.47 \mathrm{a}$ & $14.04 \mathrm{~b}$ & $17.02 \mathrm{a}$ & $34.31 \mathrm{~b}$ & $32.53 b$ \\
\hline $\mathrm{T}_{3} \cdot \mathrm{CaCl}_{2}$ at $2.0 \%$ & 0.00 & 0.00 & $0.00 \mathrm{~b}$ & 0.00 & $0.00 \mathrm{c}$ & $4.59 \mathrm{~b}$ & $4.78 \mathrm{c}$ & $10.68 b$ & $16.64 \mathrm{c}$ & $14.53 \mathrm{c}$ \\
\hline $\mathrm{T}_{4} . \mathrm{K}_{2} \mathrm{SO}_{4}$ at $1.5 \%+\mathrm{CaCl}_{2}$ at $2.0 \%$ & 0.00 & 0.00 & $0.00 \mathrm{~b}$ & 0.00 & $0.00 \mathrm{c}$ & $0.00 \mathrm{c}$ & $7.54 \mathrm{c}$ & $5.00 \mathrm{c}$ & $19.04 \mathrm{c}$ & $18.62 \mathrm{c}$ \\
\hline
\end{tabular}

Means followed by the same letter (s) in the same column don't significantly differ at 0.05 of probability according to Duncan's Multiple Range Test.

Pre-harvest spraying $\mathrm{K}_{2} \mathrm{SO}_{4}$ or $\mathrm{CaCl}_{2}$ alone or together led to the prevention of any decay incidence after 6 days cold storage compared to control, and also showed a significant decrease in fruits decay incidence $\%$ compared to control in all periods of cold storage. Calcium chloride alone or in combination with $\mathrm{K}_{2} \mathrm{SO}_{4}$ caused the lowest percentage of fruit decay incidence $\%$.

These results may be explained to the role of potassium on fruit quality by influencing size and firmness (Bhargava et al., 1993). While, the lowest values of fruit firmness and the highest weight loss and decay incidence percentages of peach fruits after 12, 18 and 24 days of cold storage were resulted from control in both seasons. These results came in the similar point of view with those reported by Gill et al. (2012), Jumaa and Ali (2016), Gayed et al. (2017), Kumar et al. (2017) and Sharma and Pratima (2018).

\section{Chemical characters:}

Means of ascorbic acid concentration (Vitamin C), titratable acidity and TSS\%, TSS/acid ratio, total soluble sugars $\%$, anthocyanin and pectic substances contents in peach fruit juice as affected by pre-harvest spraying treatments at 6-days intervals of cold storage during 2016 and 2017 seasons are recorded in Tables (2 and 3). Vitamin $\mathrm{C}$ content, acidity and total sugars percentages and pectic content in peach fruits were turn down gradually, while TSS $\%$, total soluble solids/acid ratio and anthocyanin content in peach fruits were gradually increased by increasing storage period and the rates of decline were significantly differed between the tested pre-harvest treatments in both seasons.

Data tabulated in Table (2) proved that pre-harvest spraying of $\mathrm{K}_{2} \mathrm{SO}_{4}$ or $\mathrm{CaCl}_{2}$ alone or in combination produced significantly higher fruits of vitamin $\mathrm{C}$ compared with control. The treated fruits were also preserved with higher vitamin $\mathrm{C}$ content than the control during periods of cold storage. Increasing the period of cold storage led to vitamin $\mathrm{C}$ decrease in stored fruits. The results of acidity content in fruits showed a similar trend to their vitamin $\mathrm{C}$ content.

The peach trees sprayed with potassium sulphate at the rate of $1.5 \%$ produced the highest vitamin $\mathrm{C}$ content at harvest time and after 6 and 12 days of cold in both seasons. These findings may be attributed to potassium is considered to be of most importance and is known to have profound effect on fruit quality by influencing size, color, soluble solids, acidity and vitamin content (Bhargava et al., 1993). Whilst, peach trees sprayed with calcium chloride at the rate of $2 \%$ recorded the lowest percentages of TSS and anthocyanin content in peach fruit in all storage periods in both seasons. These results may be ascribed to pre-harvest calcium treatment increased $\mathrm{Ca}$ content of the cell wall, which more effective in delaying senescence, resulting in firmer fruits and have a higher chemical quality (Raese and Drake, 2006).

At harvest time (0 day of storage), $\mathrm{TSS} \%$ was the highest in fruits treated with $\mathrm{K}_{2} \mathrm{SO}_{4}$ and the lowest in $\mathrm{CaCl}_{2}$ -treated fruits (Table 2), which means that the fruit ripening was accelerated with the first one and delayed by the second one. Prolonging the cold storage period resulted in increasing the TSS content of the stored fruit. After 24 days of cold storage, the $\mathrm{CaCl}_{2}$ - treated fruits contained 
lower $\mathrm{TSS} \%$, while the fruits treated with $\mathrm{K}_{2} \mathrm{SO}_{4}$ had the higher value. This is explained by the fact that calcium chloride delays the biochemical decomposition in the fruits, unlike the potassium sulfate. Pre-harvest spraying $\mathrm{CaCl}_{2}$ or $\mathrm{K}_{2} \mathrm{SO}_{4}$ alone or in combination resulted in a significant decrease in TSS / acid ratio in the treated fruits compared with control, at the harvest time and during cold storage periods up to 24 days (Table 2). The applying of $\mathrm{CaCl}_{2}$ and $\mathrm{K}_{2} \mathrm{SO}_{4}$ interaction gave the lowest TSS / acid ratio, due to reducing acid content of treated fruits and increasing TSS content.

Table 2. Vitamin C, titratable acidity. TSS percentages and TSS/acid ratio in peach fruit juice as affected by preharvest spraying treatments potassium sulphate, calcium chloride and their combination at 6-days intervals of cold storage during 2016 and 2017 seasons.

\begin{tabular}{|c|c|c|c|c|c|c|c|c|c|c|}
\hline \multirow{3}{*}{$\begin{array}{l}\text { Treatments } \\
\text { Seasons }\end{array}$} & \multicolumn{10}{|c|}{ Intervals of cold storage in days } \\
\hline & \multicolumn{2}{|c|}{$\mathbf{0}$} & \multicolumn{2}{|c|}{6} & \multicolumn{2}{|c|}{12} & \multicolumn{2}{|c|}{18} & \multicolumn{2}{|c|}{24} \\
\hline & 2016 & 2017 & 2016 & 2017 & 2016 & 2017 & 2016 & 2017 & 2016 & 2017 \\
\hline \multicolumn{11}{|c|}{ Vitamin C (mg/100 ml juice) } \\
\hline $\mathrm{T}_{1}$. Control treatment & $13.01 \mathrm{~b}$ & $13.54 \mathrm{~b}$ & $8.96 \mathrm{c}$ & $9.14 \mathrm{~d}$ & $6.40 \mathrm{~b}$ & $6.70 \mathrm{c}$ & $5.26 \mathrm{~b}$ & $5.29 \mathrm{c}$ & $3.46 \mathrm{~b}$ & $3.56 \mathrm{~b}$ \\
\hline $\mathrm{T}_{2} . \mathrm{K}_{2} \mathrm{SO}_{4}$ at $1.5 \%$ & $14.98 \mathrm{a}$ & $15.22 \mathrm{a}$ & $12.14 \mathrm{a}$ & $12.35 \mathrm{a}$ & $9.30 \mathrm{a}$ & $9.47 \mathrm{a}$ & $6.66 \mathrm{ab}$ & $6.80 \mathrm{~b}$ & $4.02 \mathrm{~b}$ & $5.09 \mathrm{a}$ \\
\hline $\mathrm{T}_{3} . \mathrm{CaCl}_{2}$ at $2.0 \%$ & $13.43 \mathrm{ab}$ & $14.40 \mathrm{a}$ & $9.92 \mathrm{bc}$ & $10.02 \mathrm{c}$ & $7.07 \mathrm{~b}$ & $7.25 \mathrm{~b}$ & $5.60 \mathrm{~b}$ & $5.84 \mathrm{c}$ & $4.80 \mathrm{a}$ & $4.99 \mathrm{a}$ \\
\hline $\mathrm{T}_{4} \cdot \mathrm{K}_{2} \mathrm{SO}_{4}$ at $1.5 \%$ & $14.51 \mathrm{ab}$ & $14.91 \mathrm{a}$ & $10.77 b$ & $10.85 \mathrm{~b}$ & $7.04 \mathrm{~b}$ & $7.33 b$ & $7.54 \mathrm{a}$ & $7.85 \mathrm{a}$ & $5.01 \mathrm{a}$ & $5.31 \mathrm{a}$ \\
\hline \multicolumn{11}{|c|}{ Titratable acidity (\%) } \\
\hline $\mathrm{T}_{1}$. Control treatment & $1.03 \mathrm{c}$ & $1.07 \mathrm{~b}$ & $0.82 \mathrm{c}$ & $0.87 \mathrm{c}$ & $0.62 \mathrm{c}$ & $0.67 \mathrm{~b}$ & $0.49 \mathrm{c}$ & $0.49 \mathrm{~d}$ & $0.45 \mathrm{~d}$ & $0.32 \mathrm{c}$ \\
\hline $\mathrm{T}_{2} . \mathrm{K}_{2} \mathrm{SO}_{4}$ at $1.5 \%$ & $1.33 b$ & $1.41 \mathrm{a}$ & $1.04 \mathrm{~b}$ & $1.12 \mathrm{~b}$ & $0.74 b$ & $0.83 b$ & $0.78 \mathrm{~b}$ & $0.63 \mathrm{c}$ & $0.61 \mathrm{c}$ & $0.42 \mathrm{~b}$ \\
\hline $\mathrm{T}_{3} . \mathrm{CaCl}_{2}$ at $2.0 \%$ & $1.31 b$ & $1.34 \mathrm{ab}$ & $1.06 \mathrm{~b}$ & $1.08 \mathrm{~b}$ & $0.77 b$ & $0.83 b$ & $0.72 b$ & $0.78 b$ & $0.63 b$ & $0.43 b$ \\
\hline $\mathrm{T}_{4} . \mathrm{K}_{2} \mathrm{SO}_{4}$ at $1.5 \%+\mathrm{CaCl}_{2}$ at $2.0 \%$ & $1.41 \mathrm{a}$ & $1.45 \mathrm{a}$ & $1.33 \mathrm{a}$ & $1.36 \mathrm{a}$ & $1.23 \mathrm{a}$ & $1.27 \mathrm{a}$ & $0.91 \mathrm{a}$ & $0.91 \mathrm{a}$ & $0.89 \mathrm{a}$ & $0.56 \mathrm{a}$ \\
\hline \multicolumn{11}{|c|}{ TSS (\%) } \\
\hline $\mathrm{T}_{1}$. Control trea & $8.13 \mathrm{c}$ & $8.00 \mathrm{c}$ & $8.77 \mathrm{~b}$ & $8.67 \mathrm{a}$ & $9.67 \mathrm{a}$ & $9.33 \mathrm{a}$ & $10.27 \mathrm{~b}$ & $10.00 \mathrm{c}$ & $11.13 \mathrm{c}$ & $10.67 \mathrm{~b}$ \\
\hline $\mathrm{T}_{2} . \mathrm{K}_{2} \mathrm{SO}_{4}$ at $1.5 \%$ & $8.33 \mathrm{a}$ & $8.20 \mathrm{a}$ & $9.67 \mathrm{a}$ & $9.33 \mathrm{a}$ & $10.27 \mathrm{a}$ & $10.00 \mathrm{a}$ & $11.07 \mathrm{a}$ & $11.00 \mathrm{a}$ & $12.83 \mathrm{a}$ & $12.67 \mathrm{a}$ \\
\hline $\mathrm{T}_{3 .} \mathrm{CaCl}_{2}$ at $2.0 \%$ & $8.00 \mathrm{~d}$ & $7.87 \mathrm{~d}$ & $8.43 b$ & $8.00 \mathrm{a}$ & $8.87 \mathrm{~b}$ & $8.33 \mathrm{~b}$ & $10.20 \mathrm{~b}$ & $10.00 \mathrm{c}$ & $10.50 \mathrm{~d}$ & $10.17 \mathrm{~b}$ \\
\hline $\mathrm{T}_{4} . \mathrm{K}_{2} \mathrm{SO}_{4}$ at $1.5 \%+\mathrm{CaCl}_{2}$ at $2.0 \%$ & $8.20 \mathrm{~b}$ & $8.07 \mathrm{~b}$ & $9.05 \mathrm{ab}$ & $9.00 \mathrm{a}$ & $9.97 \mathrm{a}$ & $10.00 \mathrm{a}$ & $10.93 \mathrm{a}$ & $10.27 \mathrm{~b}$ & $12.07 \mathrm{~b}$ & $12.00 \mathrm{a}$ \\
\hline \multicolumn{11}{|c|}{ TSS/acid ratio } \\
\hline $\mathrm{T}_{1}$. Control t & $7.95 \mathrm{a}$ & $7.75 \mathrm{a}$ & $10.30 \mathrm{a}$ & $10.45 \mathrm{a}$ & $15.53 \mathrm{a}$ & $14.93 \mathrm{a}$ & $24.48 \mathrm{a}$ & $20.92 \mathrm{a}$ & $42.99 \mathrm{a}$ & $41.04 \mathrm{a}$ \\
\hline $\mathrm{T}_{2} . \mathrm{K}_{2} \mathrm{SO}_{4}$ at $1.5 \%$ & $6.25 b$ & $5.89 \mathrm{~b}$ & $9.35 \mathrm{ab}$ & $8.58 \mathrm{ab}$ & $13.92 \mathrm{a}$ & $12.44 \mathrm{ab}$ & $15.40 \mathrm{~b}$ & $14.10 \mathrm{c}$ & $30.07 \mathrm{~b}$ & $28.43 b$ \\
\hline $\mathrm{T}_{3 .} \mathrm{CaCl}_{2}$ at $2.0 \%$ & $6.12 b$ & $5.87 \mathrm{~b}$ & $8.27 \mathrm{~b}$ & $7.41 b$ & $11.59 b$ & $10.13 b$ & $16.84 b$ & $16.00 \mathrm{~b}$ & $26.22 \mathrm{bc}$ & $24.55 \mathrm{bc}$ \\
\hline $\mathrm{T}_{4} \cdot \mathrm{K}_{2} \mathrm{SO}_{4}$ at $1.5 \%+\mathrm{CaCl}_{2}$ at $2.0 \%$ & $5.76 \mathrm{c}$ & $5.51 \mathrm{~b}$ & $6.79 \mathrm{c}$ & $6.37 \mathrm{~b}$ & $8.09 \mathrm{c}$ & $7.36 \mathrm{c}$ & $11.55 \mathrm{c}$ & $10.92 \mathrm{~d}$ & $21.15 \mathrm{c}$ & $19.14 \mathrm{c}$ \\
\hline
\end{tabular}

Means followed by the same letter (s) in the same column don't significantly differ at 0.05 of probability according to Duncan's Multiple Range Test.

The fruits obtained from pre-harvest spraying with $\mathrm{CaCl}_{2}$ or $\mathrm{K}_{2} \mathrm{SO}_{4}$ or both were significantly higher in total sugar content at the harvest date and retained the higher total sugar content during periods of cold storage compared to control fruits (Table 3). The concentration of total sugars was increased significantly by foliar application of potassium at varying concentrations as compared to control. Similar results were observed by Pandey et al. (1988) in guava fruits and Gill et al. (2012) in pear. These results came in the similar point of view with those reported by Ben et al. (2009); Gill et al. (2012); Kaur et al., (2012); Prasad et al. (2015); Gayed et al. (2017); Kumar et al. (2017), Singh et al., (2017) and Sharma and Pratima (2018).

Table 3. Total soluble sugars percentage, anthocyanin and pectic substances contents in peach fruit as affected by pre-harvest spraying treatments potassium sulphate, calcium chloride and their combination at 6-days intervals of cold storage during 2016 and 2017 seasons.

\begin{tabular}{|c|c|c|c|c|c|c|c|c|c|c|}
\hline \multirow{3}{*}{$\begin{array}{l}\text { Treatments } \\
\text { Seasons } \\
\end{array}$} & \multicolumn{10}{|c|}{ Intervals of cold storage in days } \\
\hline & \multicolumn{2}{|c|}{$\mathbf{0}$} & \multicolumn{2}{|c|}{6} & \multicolumn{2}{|c|}{12} & \multicolumn{2}{|c|}{18} & \multicolumn{2}{|c|}{24} \\
\hline & 2016 & 2017 & 2016 & 2017 & 2016 & 2017 & 2016 & 2017 & 2016 & 2017 \\
\hline \multicolumn{11}{|c|}{ Total sugars (\%) } \\
\hline $\mathrm{T}_{1}$. Control treatment & $6.89 b$ & $7.10 \mathrm{~b}$ & $6.46 b$ & $6.68 b$ & $5.90 \mathrm{a}$ & $6.23 \mathrm{a}$ & $5.61 b$ & $5.90 \mathrm{a}$ & $5.32 \mathrm{~b}$ & $5.56 \mathrm{~b}$ \\
\hline $\mathrm{T}_{2} . \mathrm{K}_{2} \mathrm{SO}_{4}$ at $1.5 \%$ & $7.44 \mathrm{a}$ & $7.63 \mathrm{a}$ & $7.00 \mathrm{a}$ & $7.25 \mathrm{ab}$ & $6.41 \mathrm{a}$ & $6.74 a$ & $6.13 \mathrm{ab}$ & $6.41 \mathrm{a}$ & $5.84 \mathrm{~b}$ & $6.08 \mathrm{a}$ \\
\hline $\mathrm{T}_{3} . \mathrm{CaCl}_{2}$ at $2.0 \%$ & $7.34 \mathrm{a}$ & $7.53 \mathrm{ab}$ & $6.90 \mathrm{ab}$ & $7.14 \mathrm{ab}$ & $6.31 \mathrm{a}$ & $6.65 \mathrm{a}$ & $5.95 \mathrm{ab}$ & $6.31 \mathrm{a}$ & $5.59 \mathrm{ab}$ & $5.97 \mathrm{a}$ \\
\hline $\mathrm{T}_{4} . \mathrm{K}_{2} \mathrm{SO}_{4}$ at $1.5 \%+\mathrm{CaCl}_{2}$ at $2.0 \%$ & $7.56 \mathrm{a}$ & $7.75 \mathrm{a}$ & $7.12 \mathrm{a}$ & $7.37 \mathrm{a}$ & $6.51 \mathrm{a}$ & $6.86 \mathrm{a}$ & $6.24 \mathrm{a}$ & $6.51 \mathrm{a}$ & $5.96 \mathrm{a}$ & $6.16 \mathrm{a}$ \\
\hline \multicolumn{11}{|c|}{ Anthocyanin (mg/100 g) } \\
\hline $\mathrm{T}_{1}$. Control treatment & $3.02 \mathrm{c}$ & $2.94 \mathrm{c}$ & $4.65 \mathrm{c}$ & $4.51 \mathrm{c}$ & $5.42 \mathrm{~b}$ & $5.36 \mathrm{c}$ & $5.50 \mathrm{~b}$ & $5.41 \mathrm{c}$ & $6.27 \mathrm{c}$ & $5.98 \mathrm{c}$ \\
\hline $\mathrm{T}_{2} . \mathrm{K}_{2} \mathrm{SO}_{4}$ at $1.5 \%$ & $5.73 b$ & $5.55 \mathrm{~b}$ & $5.84 \mathrm{~d}$ & $5.71 d$ & $6.10 \mathrm{ab}$ & $5.88 b$ & $6.52 \mathrm{a}$ & $6.27 \mathrm{~b}$ & $6.96 b$ & $6.94 b$ \\
\hline $\mathrm{T}_{3} \mathrm{CaCl}_{2}$ at $2.0 \%$ & $2.07 \mathrm{~d}$ & $1.99 \mathrm{~d}$ & $2.82 b$ & $2.66 \mathrm{~b}$ & $3.53 \mathrm{c}$ & $3.30 \mathrm{~d}$ & $4.57 \mathrm{c}$ & $4.33 \mathrm{~d}$ & $4.75 d$ & $4.56 \mathrm{~d}$ \\
\hline $\mathrm{T}_{4} . \mathrm{K}_{2} \mathrm{SO}_{4}$ at $1.5 \%+\mathrm{CaCl}_{2}$ at $2.0 \%$ & $6.44 \mathrm{a}$ & $6.20 \mathrm{a}$ & $6.57 \mathrm{a}$ & $6.52 \mathrm{a}$ & $6.70 \mathrm{a}$ & $6.61 \mathrm{a}$ & $6.94 \mathrm{a}$ & $6.85 \mathrm{a}$ & $9.34 \mathrm{a}$ & $8.56 \mathrm{a}$ \\
\hline \multicolumn{11}{|c|}{ Pectic substances content (\%) } \\
\hline $\mathrm{T}_{1}$. Control treatment & $16.26 \mathrm{~d}$ & $16.56 \mathrm{c}$ & $15.77 \mathrm{~d}$ & $16.08 \mathrm{~d}$ & $15.19 \mathrm{a}$ & $15.43 \mathrm{a}$ & $14.34 b$ & $14.60 \mathrm{~b}$ & $13.49 \mathrm{~b}$ & $13.76 b$ \\
\hline $\mathrm{T}_{2} . \mathrm{K}_{2} \mathrm{SO}_{4}$ at $1.5 \%$ & $17.22 \mathrm{c}$ & $17.58 \mathrm{a}$ & $16.95 b$ & $17.05 b$ & $16.09 \mathrm{a}$ & $16.26 \mathrm{a}$ & $15.73 \mathrm{a}$ & $15.94 a$ & $15.36 \mathrm{a}$ & $15.61 \mathrm{a}$ \\
\hline $\mathrm{T}_{3} \mathrm{CaCl}_{2}$ at $2.0 \%$ & $17.03 \mathrm{c}$ & $17.36 b$ & $16.62 \mathrm{c}$ & $16.84 \mathrm{c}$ & $15.83 \mathrm{a}$ & $16.08 \mathrm{a}$ & $15.57 \mathrm{a}$ & $15.76 \mathrm{a}$ & $15.31 \mathrm{a}$ & $15.44 \mathrm{a}$ \\
\hline $\mathrm{T}_{4} . \mathrm{K}_{2} \mathrm{SO}_{4}$ at $1.5 \%+\mathrm{CaCl}_{2}$ at $2.0 \%$ & $17.54 \mathrm{a}$ & $17.74 \mathrm{a}$ & $17.06 \mathrm{a}$ & $17.26 \mathrm{a}$ & $16.21 \mathrm{a}$ & $16.43 \mathrm{a}$ & $15.89 a$ & $16.11 \mathrm{a}$ & $15.57 \mathrm{a}$ & $15.79 \mathrm{a}$ \\
\hline
\end{tabular}

Means followed by the same letter (s) in the same column don't significantly differ at 0.05 of probability according to Duncan's Multiple Range Test. 
The pre-harvest spraying of $\mathrm{CaCl}_{2}$ caused a decrease in the concentration of anthocyanins in fruit skin compared to the control and $\mathrm{K}_{2} \mathrm{SO}_{4}$ at harvest time and during the intervals periods of cold storage (Table 3). The combination treatment of $\mathrm{K}_{2} \mathrm{SO}_{4}$ and $\mathrm{CaCl}_{2}$ showed the highest content of anthocyanin in fruit skin at the harvest date and during cold storage periods. The concentration of anthocyanins in the skin of peach fruits was increased with an increase in cold storage period.

Pre-harvesting application of $\mathrm{CaCl}_{2}$ or $\mathrm{K}_{2} \mathrm{SO}_{4}$ alone or in combination resulted in a significant increase in the pectin content of the fruits, at harvest date and during cold storage periods up to 24 days compared to control (Table 3). Calcium and pectin contents are very important for good fruit quality. Whearas, Inserting $\mathrm{Ca}^{2+}$ into a polygalacturon chain supplies a strong structure (Grant et al., 1973) in which $\mathrm{Ca}^{2+}$ plays chemical and structural roles that effect on the enzmes action like pectinesterase and polygalacturonase on the pectin polymer and thus on texture and firmness of the vegetables and fruits that is very important for fruits storage and processing (Rigney and Wills, 1981). As well as, $\mathrm{Ca}^{2+}$ treatment also raise cell turgor and this too could effect tissue firmness (Labavitch and Mignanim 1993).

\section{CONCLUSION}

From obtained data in this study; it could be recommended spraying peach trees at pre-harvest with the combination treatment of potassium sulphate $(1.5 \%)$ and calcium chloride (2\%) to improve quality and chemical characters of peach fruits during cold storage.

\section{REFERENCES}

Alandes, L. ; I. Perez ; E. Llarca ; A. Quiles and I. Hernondo (2009). Use of calcium lactate to improve structure of "Flor de Invierno" fresh cut Pears. Postharvest Biol. \& Technol., 53 :145-151.

Ben, M.M. ; M. Ghrab ; M. Ghanem and O. Elloumi (2009). Effects of potassium foliar spray on olive, peach and plum. Acta Hort., 586: 507-513.

Bhargava, B.S. ; H.P. Singh and K.L. Chadha (1993). Role of potassium in development of fruit quality. In: Adv. in Hort., Vol. 2 Fruit Crops: Part 2. K.L. Chadha and O.P. Pareek (Eds.). Malhotra Publishing House, New Delhi, pp: 947-960.

Dong, X. ; R.E. Wrolstad and D. Sugar (2000). Extending shelf life of fresh-cut pears. J. Food Sci., 65 : 181186.

Eliwa, G.I.(2005).Approach to new Peach cultivars by aid of horticultural studies on Mit-Ghamer peach chosen Univ.30(8):4649-4663.

Ernani, P.R. ; C.V.T. Amarante ; J. Dias; and A.A. Bessegato (2002). Preharvest calcium sprays improve fruit quality of "Gala" apples in Southern Brazil. Acta Horticulturae 86, 481-594.

FAO (2019). Food and Agriculture Organization. Faostat, FAO Statistics Division, February, 2019.

Francis F.J. and C.D. Chiriboga (1973). Ion Exchange purified anthocyanin pigments as a colorant for cranberry juice Cocktail. Journal of Food Science, 38(3):464-467.
Gad, M.M. ; O.A. Zagzog and O.M. Hemeda (2016). Development of nano-chitosan edible coating for peach fruits cv. Desert Red. Intern. J. Environ., 5(4): 43-55.

Gayed, A.A.A. ; Samar, A.M.A. Shaarawi ; M.A. Elkhishen ; N.R.M. Elsherbini (2017). Pre-harvest application of calcium chloride and chitosan on fruit quality and storability of 'Early Swelling' peach during cold storage. Ciencia e Agrotecnologia, 41(2): 220-231.

Gill, P.S. ; M.Y. Ganaie ; W.S. Dhillon and N.P. Singh (2012). Effect of foliar sprays of potassium on fruit size and quality of 'Patharnakh' pear. Indian J. Hort., 69(4): 512-516.

Glenn, G. M. and B. W. Poovaiah (1990). Calciummediated postharvest changes in texture and cell wall structure and composition in "Golden Delicious" apples. J. Amer. Soc. Hort. Sci., 115(6): 962-968.

Grant, G. T. ; E. R. Morris; D. A.Rees; P. J. C. Smith and D. Thom (1973). Biological interaction between polysaccharides and divalent cations: the egg box model. FEBS Lett. 32: 195-198.

Husia, C. L.; B. S. Luh and C. D. Chichester .(1965).Anthocyanin in free stone peach. J. Food Science, 30: 5-12.

Hussain, P.R. ; R.S. Meena ; M.A Dar and A.M. Wani (2008). Studies on enhancing the keeping quality of peach (Prunus persica Bausch) cv. Elberta by gamma-irradiation. Rad. Physiol. Chem., 77: 473481.

Jumaa, F.F. and A.A. Ali (2016). Effect of foliar application of potassium zinc and gibberelic acid on yield and some fruit quality of pomegranate cv. Salimy. The Iraqi J. Agric. Sci., 47(2): 524-532.

Kaur, A.P.; H. Singh and S.K. Jawandha (2012). Effect of pre-harvest application on nutrients and growth regulator on fruit quality of sub-tropical peach. Asian J. Hort., 7(2): 565-568.

Kaur, M. and A. Kaur (2019). Improvement in storability and quality of peach cv. Flordaprince with postharvest application of various chemicals. J. Pharma. and Phytochem., 8(1): 460-464.

Kumar, G.K. ; V.S. Vani ; A.D. Rao ; P. Subbaramamma and R.V. Sujatha (2017). Effect of foliar sprays of urea, potassium sulphate and zinc sulphate on quality of guava cv. Taiwan pink. Intern. J. Chem. Studies, 5(5): 680-682.

Labavitch, J. M. and I. Mignanim (1993). Studio degli effetti del calico e degli altri ioni sulla maturazione del frutto. Rivista di Frutticoltura, (3): 81-83.

Magness, J.R. and C.F. Taylor (1925). An improved type of pressure tester for the determination of fruit maturity. U.S. Dept. Agric. Circ. No. 350, PP. 8.

Matzner, F. and E. Maurer (1975). Cherry. In : Bose, T.K. ; S.K. Mitra and M.K. Sandhu (Eds.). Mineral Nutrition of Fruit Crops. pp 602-616., Naya Prakash Calcutta, India. 
Pandey, D. K. ; R. A. Pathak, and R. K Pathak. (1988). Studies on the foliar application of nutrients and plant growth regulators in Sardar guava (Psidium guajava L.) I. Effect on yield and fruit quality. Indian J. Hort., 45: 197-202.

Prasad, B.; D.C. Dimri and L. Bora (2015). Effect of preharvest foliar spray of calcium and potassium on fruit quality of Pear cv. Pathernakh. Sci. Res. and Essays, 10(11): 376-380.

Raese, J.T. and S.R. Drake (2006). Calcium foliar sprays for control of alfalfa greening, cork spot, and hard end in 'Anjou' Pears. J. Plant Nut., 29(3): 543-552.

Ranganna, S. (1979). Manual of Analysis of Fruit and Vegetable Products. $2^{\text {nd }}$ Ed. Tata Mcgraw. Hill, publishing company Limited, New Delhi, pp. 634.

Rigney, C. J. and R. B. H. Wills (1981). Calcium movement, a regulating, factor in the initiation of tomato fruit ripening. HortSci., 16(4): 550-551.

Sadasivam S. and A. Manickam (1996). Biochemical Methods, $2^{\text {nd }}$ Ed., New Age Intern. India.
SAS (1996).Analytical Software of Solutions: Statistics, version $5^{\text {th }}$ Ed. SAS Institute, Inc. Cary, NC, USA.

Sharma, S.K. and P. Pratima (2018). Effect of pre-harvest gibberellic acid and calcium application on postharvest behaviour of subtropical peaches. Current Agric. Res. J., 6(1): 78-84.

Singh, M.; A. Jasrotia; P. Bakshi; V.K. Wali; R. Kumar and K. Kour (2017). Effect of various storage conditions and calcium treatments on physicochemical properties of peach (Prunus persica) cv. Shan-e-Punjab. Indian J. Agric. Sci., 87 (6):796800

Wang, L.; S. Chen; W. Kong; S. Li; and D.D. Archbold (2006). Salicylic acid pretreatment alleviates chilling injury and affects the antioxidant system and heat shock proteins of peaches during cold storage. Postharvest Biol. Technol., 41: 244-251.

Wani, W. M. and M. H. Khajwall (1997). Effect of soil and foliar application of nutrients on physical and chemical characters of pear fruit cv. Bartlett.Adv. Plant Sci., 10: 111-114.

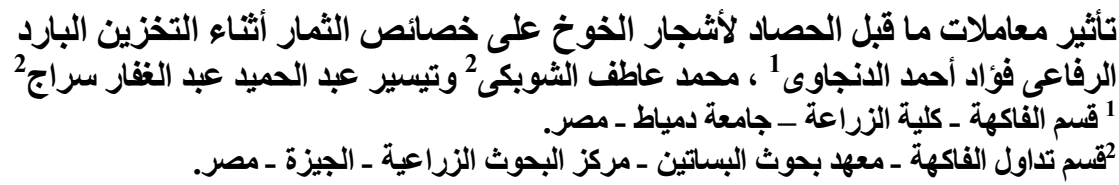

أجريت هذه الدراسة خلال موسمي 2016 و 2017 على أشنجار خوخ منزر الجة في بستان تجاري لدر اسة تأثير معاملات ما قبل الحصاد

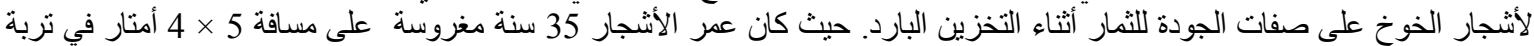

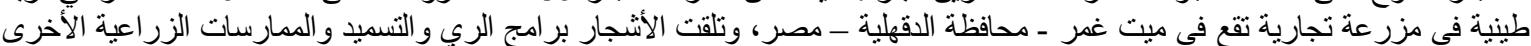

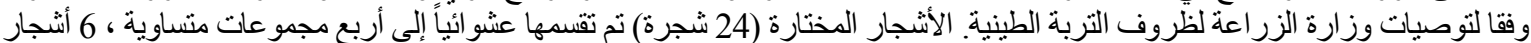

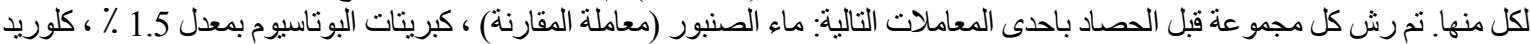

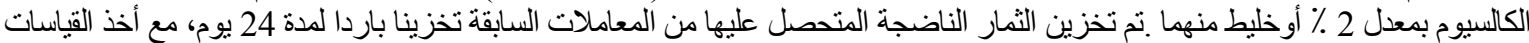

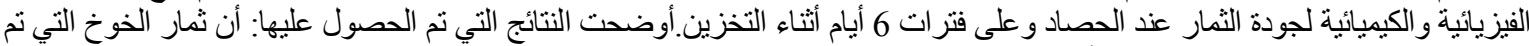
رشها بـ بـ

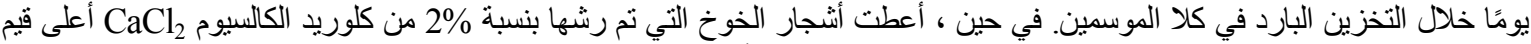

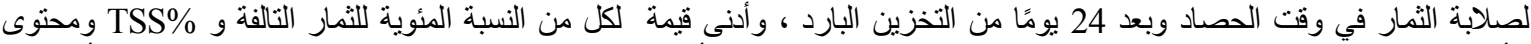

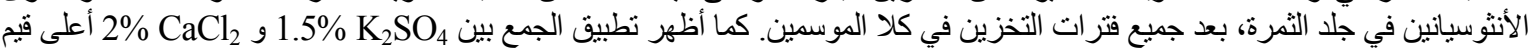

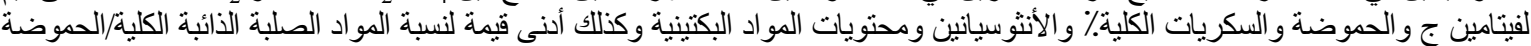

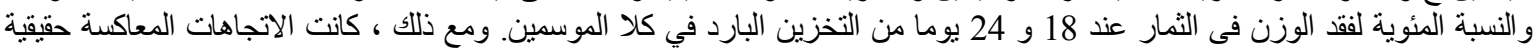

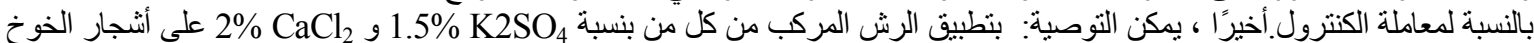

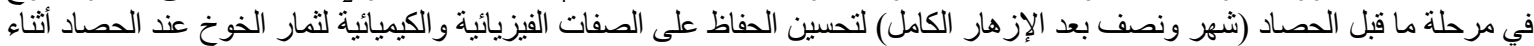
التخزين البارد لمدة تصل مل فلى اللى 24 يومًا . 